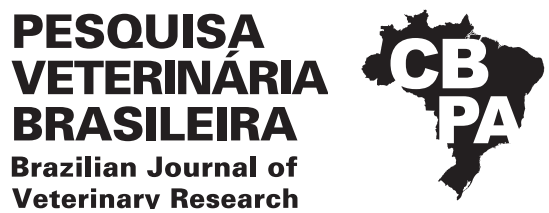

\title{
Acute-phase protein concentration in bronchoalveolar lavage fluid from healthy horses ${ }^{1}$
}

\author{
Paula Alessandra Di Filippo ${ }^{2 *}$ (D), Luiza Maria F. Ribeiro², \\ Marcos Aurélio D. Meireles ${ }^{3}$, Francielli P. Gobbi ${ }^{2}$ \\ and Andressa Francisca S. Nogueira ${ }^{4}$
}

\begin{abstract}
Di Filippo P.A., Ribeiro L.M.F., Meireles M.A.D., Gobbi F.P. \& Nogueira A.F.S. 2020. Acute-phase protein concentration in bronchoalveolar lavage fluid from healthy horses. Pesquisa Veterinária Brasileira 40(12):1073-1076. Laboratório de Clínicas e Cirurgia Veterinária, Centro de Ciências e Tecnologias Agropecuárias, Universidade Estadual do NorteFluminense Darcy Ribeiro, Av. Alberto Lamego 2000, Campos dos Goytacazes, RJ 28013-602, Brazil. E-mail: pdf@uenf.br

Bronchoalveolar lavage fluid (BALF) was analyzed to obtain information on leakage of acute-phase proteins from the blood into the respiratory lumen and about local synthesis. Ceruloplasmin, transferrin, albumin, $\alpha_{1}$-antitripsin, immunoglobulin $\mathrm{G}$ heavy, immunoglobulin G light, immunoglobulin A, haptoglobin, acidic glycoprotein, and P23 were measured in BALF from 30 horses without inflammatory disease by sodium dodecyl sulfate polyacrylamide gel electrophoresis (SDS-PAGE). In serum, the same proteins were identified except for $\alpha_{1}$ antitrypsin. In conclusion, this study demonstrated that polyacrylamide gel electrophoresis (SDS-PAGE) can be used for the determination of acute-phase proteins in BALF samples from horses. In healthy horses, the values are very low, but they can be compared with reference values to assist in the diagnosis of animals with respiratory diseases.
\end{abstract}

INDEX TERMS: Acute-phase, protein, bronchoalveolar lavage, healthy horses, inflammatory airway disease, inflammatory biomarker, electrophoresis, equine.

\begin{abstract}
RESUMO.- [Proteínas de fase aguda do lavado broncoalveolar de equinos hígidos.] 0 líquido obtido através da lavagem broncoalveolar (LBA) foi analisado para obter informações sobre as proteínas da fase aguda. Ceruloplasmina, transferrina, albumina, $\alpha 1$-antitripsina, imunoglobulina G pesada, imunoglobulina G leve, imunoglobulina $\mathrm{A}$, haptoglobina, glicoproteína ácida e P23 foram medidas nos LBA de 30 cavalos sem doença inflamatória por eletroforese em gel de poliacrilamida com dodecilsulfato de sódio (SDS-PAGE). No soro, as mesmas proteínas foram identificadas, exceto a $\alpha 1$-antitripsina. Em conclusão, este estudo demonstra que
\end{abstract}

\footnotetext{
${ }^{1}$ Received on June 9, 2020.

Accepted for publication on September 10, 2020.

${ }^{2}$ Laboratório de Clínicas e Cirurgia Veterinária (LCCA), Centro de Ciências e Tecnologias Agropecuárias (CCTA), Universidade Estadual do Norte Fluminense Darcy Ribeiro (UENF), Av. Alberto Lamego 2000, Parque Califórnia, Campos dos Goytacazes, RJ 28013-602, Brazil. E-mails: f.feitosaribeiro@gmail.com, franci_gobbi@hotmail.com; *Corresponding author: pdf@uenf.br

${ }^{3}$ Instituto Federal de Minas Gerais (IFMG), Campus Bambuí, Fazenda Varginha, Rodovia Bambuí/Medeiros Km 5, Bambuí, MG 38900-000, Brazil. E-mail: marcosadmeireles@yahoo.com.br

${ }^{4}$ Universidade Federal do Tocantins (UFT), Rua Dois 34, Conj. Res. Patrocínio, Araguaína, T0 65907-230, Brazil. E-mail: dessafsn@yahoo.com.br
}

a eletroforese em gel de poliacrilamida (SDS-PAGE) pode ser usada para a determinação de proteínas de fase aguda em amostras de LBA em cavalos. Em cavalos saudáveis, os valores são muito baixos, no entanto, podem ser comparados e auxiliar no diagnóstico de animais com doenças respiratórias.

TERMOS DE INDEXAÇÃO: Proteína, fase aguda, lavado, broncoalveolar, equinos hígidos, inflamação das vias aéreas, biomarcador inflamatório, eletroforese equina.

\section{INTRODUCTION}

The lungs and airways are mucosal surfaces commonly exposed to invading pathogens and environmental contaminants (Kyd et al. 2001). As a result, the airway inflammatory airway disease (IAD) is a common cause of poor performance, exercise intolerance, interruption of training, and premature retirement of horses (Sweeney et al. 1992, Wilkins 2003, Couëtil et al. 2007). However, recognition of IAD in a horse usually requires more than just clinical assessment, because many horses do not display obvious clinical signs. In these cases, the implementation of biomarkers specific for lung inflammation can facilitate its diagnosis (Bullone et al. 2015). 
In equine medicine, measurement of acute-phase proteins (APPs) is used to determine of the presence, prognosis, degree and time course of inflammation, since these proteins are released in large quantities to the bloodstream in response to infection or traumatic injury (Hultén \& Demmers 2002).

Acute-phase proteins modulate leukocyte function and migration, activating the complement cascade, preventing the loss of iron through the formation of stable complexes with free hemoglobin, and in some cases presenting antiinflammatory properties (Crisman et al. 2008). While the main source is the liver, some acute-phase proteins are also produced in the lungs (Yang et al. 1995, Upragarin et al. 2005). Measuring local levels of APP increases the accuracy of diagnosis by providing information on the inflammatory/ infectious status of the organ of specific interest (Jacobsen 2007). However, this potential has been little explored in horses. The aim of this study was to measure the acute-phase proteins in bronchoalveolar lavage fluid (BALF) of healthy horses, to identify and quantify local markers that can help discriminate horses with and without airway inflammation.

\section{MATERIALS AND METHODS}

This study was approved by the ethics committee on animal experiments of Darcy Ribeiro Norte Fluminense State University (CEUA-UENF) under protocol number 901139. Horses were examined for 3 successive days from the day of admission until discharge. A total of 30 crossbreed female horses (age $5 \pm 2$ years, BDW $400 \pm 25 \mathrm{~kg}$ ) were examined, which had no clinical signs or history of respiratory disease. All horses were kept in semi-confinement, in $10 \mathrm{~m}^{2}$ stalls with cement floor and no bedding. Feeding included 3 to $4 \mathrm{~kg} /$ day of commercial horse concentrate per animal, containing 12\% total protein, $4 \mathrm{~kg}$ of Coast-Cross hay/animal per day, mineral salt, and water ad libitum. The animals were dewormed every four months and vaccinated against influenza, tetanus, rabies, equine adenitis, and leptospirosis. The horses had no history of respiratory disease, no acute signs of infection (leukocytosis, fever, depression), no tracheal secretions, low cellular density and neutrophils $\leq 10 \%$ in BALF cytology or medical treatment during the 30 days preceding data collection. The animals included were considered healthy after a routine physical evaluation, pulmonary auscultation and percussion, endoscopic examination, complete blood count, and cytological analysis of bronchoalveolar lavage fluid, according to the values described by Viscardi et al. (2015), and Couëtil et al. (2016).

Bronchoalveolar lavage was performed with the horses standing using a special silicone BAL catheter (BIVONA ${ }^{\circledR}$ ), under mild sedation (detomidine, $0.5 \mathrm{mg} / \mathrm{kg}$ bwt i.v). The catheter was placed through the nostril, advanced through the trachea until it became trapped in a distal bronchus. The cuff was then filled with $8 \mathrm{~mL}$ of air, and $250 \mathrm{~mL}$ of warm $\left(37^{\circ} \mathrm{C}\right)$ sterile $0.9 \%$ saline, divided into 3 boluses, were sequentially instilled and immediately aspired. Samples were considered adequate if at least $40 \%$ of the infused liquid was recovered and when surfactant action and turbidity were observed. After collection, the aliquots of BALF were pooled and macroscopically examined to evaluate the color, transparency, and presence of flocculent debris. Flocculent samples were filtered through two layers of gauze to remove excess mucus strands and other debris.

The samples were maintained at $-4^{\circ} \mathrm{C}$ in sterile test tubes for cytological processing and at $-20^{\circ} \mathrm{C}$ for APP determination. Within 1 hour of collection, the samples used in the cytological analysis were cytocentrifuged (Cytopro 7620, Wescor ${ }^{\circledR}$ ) at $110 \mathrm{~g}$ for $5 \mathrm{~min}$ and stained with May-Grunwald Giemsa solution $\left(\right.$ Merck $\left.^{\circledR}\right)$. Differential cell counts were performed by counting 500 cells, excluding epithelial cells.

Venous blood samples $(7 \mathrm{~mL})$ were collected from the jugular vein with a Vacutainer (BD) into plain tubes. Samples were centrifuged $(1500 \mathrm{~g}, 10 \mathrm{~min})$ and the serum separated and stored at $-20^{\circ} \mathrm{C}$ for subsequent laboratory analysis.

Total protein levels in serum $(\mathrm{g} / \mathrm{dL})$ and BALF $(\mathrm{mg} / \mathrm{dL})$ were measured according to the biuret protein assay using a set of diagnostic reagents (Labtest, Sistema de Diagnósticos Ltda., Lagoa Santa, Brazil) and spectrophotometric readings (Biosystem ${ }^{\circledR}$ - BTS350). After protein measurements, the BALF samples were submitted to lyophilization (LioTop L-101). Protein fractions were determined by sodium dodecyl sulfate polyacrylamide gel electrophoresis (SDSPAGE). Molecular weights and concentrations of protein fractions were determined by computed videodensitometry (CS 9000, Shimadzu Corp., Kyoto, Japan). Reference markers (Sigma Chemical Co., St Louis, USA) were used to characterize proteins, with molecular weights of $29,45,66,97.4,116$, and $205 \mathrm{kDa}$. Also, electrophoretic migration of proteins was compared with that of pure proteins including albumin, transferrin, haptoglobin, ceruloplasmin, IgA, IgG, $\alpha 1$-antitripsin, and acidic glycoprotein.

The data obtained were submitted to descriptive analysis, and means, maximum and minimum values were determined using the SAS statistical program.

\section{RESULTS}

The BALF cytology profiles of the healthy horses are summarized in Table 1 and were characterized by the prevalence of alveolar macrophages and lymphocytes, followed by neutrophils, mast cells, eosinophils and a small percentage of epithelial cells. These results are similar to the findings described by Viscardi et al. (2015), Wysocka \& Kluciński (2015) and in a Consensus Statement of the American College of Veterinary Internal Medicine (Couëtil et al., 2016) for healthy horses.

Twenty-five proteins with molecular weights between 21 and $230 \mathrm{kDa}$ were identified in BALF of horses. BALF levels of proteins of $174 \mathrm{kDa}$ (immunoglobulin A), $106 \mathrm{kDa}$ (ceruloplasmin), $80 \mathrm{kDa}$ (transferrin), 63kDa (albumin), $58 \mathrm{kDa}\left(\alpha_{1}\right.$-antitripsin), $54 \mathrm{kDa}$ (immunoglobulin G heavy), 42kDa (haptoglobin), 34kDa (acidic glycoprotein), 24kDa (immunoglobulin G light), and $23 \mathrm{kDa}$ (P23) were nominally identified (Table 2).

In serum, 21 proteins with molecular weights between 21 and $255 \mathrm{kDa}$ were identified in all animals. Serum levels of proteins of $171 \mathrm{kDa}$ (immunoglobulin A), 106kDa (celuloplasmin), 80 $\mathrm{kDa}$ (transferrin), 59kDa (albumin), 51kDa (immunoglobulin G heavy), 41kDa (haptoglobin), 35kDa (acidic glycoprotein), $24 \mathrm{kDa}$ (immunoglobulin G light), and 23kDa (P23) were nominally identified (Table 2).

Table 1. Percentage of cells recovered from bronchoalveolar lavage fluid of healthy horses

\begin{tabular}{|c|c|c|c|c|c|}
\hline \multicolumn{6}{|c|}{ Percentage of cells } \\
\hline Macrophages & Lymphocytes & Neutrophils & Eosinophils & Mast cells & Epithelial cells \\
\hline $43.80 \pm 17.01$ & $36.4 \pm 21.54$ & $4.6 \pm 3.80$ & $1.8 \pm 0.84$ & $1.60 \pm 0.84$ & $0.70 \pm 1.90$ \\
\hline
\end{tabular}


Table 2. Serum and bronchoalveolar fluid protein concentrations (mean \pm SD) in healthy horses determined by sodium dodecyl sulfate-polyacrylamide gel electrophoresis

\begin{tabular}{|c|c|c|c|c|c|c|}
\hline \multirow{3}{*}{ Protein } & \multicolumn{6}{|c|}{ Horses } \\
\hline & \multicolumn{3}{|c|}{ Serum (g/dL) } & \multicolumn{3}{|c|}{$\mathrm{BALF}(\mathrm{mg} / \mathrm{dL})$} \\
\hline & $\mathrm{M} \pm \mathrm{SD}$ & Max & Min & $\mathrm{M} \pm \mathrm{SD}$ & Max & Min \\
\hline Total serum protein & $9.63 \pm 0.86$ & 11.64 & 8.71 & $18.52 \pm 10.93$ & 39.0 & 7.97 \\
\hline Albumin & $5.63 \pm 0.63$ & 7.18 & 5.01 & $9.94 \pm 7.66$ & 24.44 & 2.59 \\
\hline Ceruloplasmin & $0.028 \pm 0.007$ & 0.015 & 0.041 & $0.04 \pm 0.03$ & 0.11 & 0.005 \\
\hline Transferrin & $0.72 \pm 0.12$ & 0.93 & 0.55 & $1.43 \pm 0.74$ & 2.87 & 0.63 \\
\hline Haptoglobin & $0.06 \pm 0.01$ & 0.09 & 0.04 & $0.29 \pm 0.15$ & 0.50 & 0.03 \\
\hline Acid glycoprotein & $0.011 \pm 0.002$ & 0.015 & 0.009 & $0.90 \pm 0.54$ & 1.64 & 0.09 \\
\hline $\operatorname{IgA}$ & $0.23 \pm 0.04$ & 0.29 & 0.15 & $0.96 \pm 0.08$ & 0.32 & 0.01 \\
\hline IgG heavy & $1.19 \pm 0.21$ & 1.65 & 0.82 & $1.17 \pm 0.83$ & 2.32 & 0.03 \\
\hline IgG light & $1.11 \pm 0.28$ & 1.54 & 0.68 & $2.12 \pm 1.74$ & 5.83 & 0.27 \\
\hline$\alpha 1$-antitripsin & - & - & - & $1.22 \pm 0.87$ & 2.43 & 0.29 \\
\hline P23 & $0.43 \pm 0.002$ & 1.54 & 0.68 & $0.12 \pm 0.10$ & 0.36 & 0.04 \\
\hline
\end{tabular}

\section{DISCUSSION}

In this study, we evaluated healthy horses without clinical signs of respiratory disease and found that by applying electrophoresis (SDS-PAGE), the concentrations in BALF of ceruloplasmin, transferrin, albumin, $\alpha_{1}$-antitripsin, immunoglobulin $\mathrm{G}$ heavy, immunoglobulin G light, immunoglobulin A, haptoglobin and acidic glycoprotein can be assessed. These proteins can also be measured in BALF or serum by ELISA, as described by Out et al. (1987) and Barton et al. (2017). Albumin, ceruloplasmin and alpha-2-macroglobulin were measured in paired BALF and serum samples from human patients with acute pneumonitis or asthma. The results indicated that abnormal leakage of proteins from the blood rather than local synthesis causes the increased concentrations of these proteins in BALF and that the determination of ceruloplasmin and alpha-2macroglobulin yields more detailed information on leakage of proteins from the blood into the airway compartment than that of albumin (Out et al. 1987). Fibrinogen (Fb) and serum amyloid A (SAA) concentrations were measured in BALF of horses with respiratory disease. Although no significant differences were found between control groups compared to groups with recurrent airway obstruction, inflammatory airway disease or chronic interstitial pneumopathy, the fibrinogen concentration was positively correlated with the percentage of neutrophils in BALF cytology (Barton et al. 2017). Several functions have been ascribed to $\mathrm{Fb}$, including providing a substrate for fibrin formation during tissue repair and providing a matrix for migration of inflammatory-related cells. Fb binds to cell surface integrins (CD11/CD18) of phagocytes, initiating a cascade of intracellular signals and promoting the enhancement of degranulation, phagocytosis, and antibody-dependent cytotoxicity (Borges et al. 2007).

In IAD-affected horses, high BALF albumin and IgG concentrations were consistent with leakage of plasma proteins into the airway lumen, but local Ig production cannot be excluded in IAD-affected horses. In fact, the magnitude of increase in BALF IgA concentrations was higher than expected from exudation of plasma proteins, which may indicate the presence of local IgA production (Moore et al. 1997). Exudation of plasma proteins into the airway lumen results from loss of vascular integrity of the subepithelial plexus secondary to subepithelial inflammation. Plasma exudation occurs independent of cellular diapedesis and migration and is not necessarily observed in all types of pulmonary inflammatory diseases (Persson 1991). Secretoglobin expression in BALF was significantly higher in horses with recurrent airway obstruction (RAO) compared to that in the control horses and inflammatory airway disease-affected horses (Miskovic Feutz et al. 2015). Secretoglobin is an anti-inflammatory protein that inactivates phospholipase A2, decreases proinflammatory cytokine production, alters phagocyte function, and may decrease the inflammatory response to endotoxin (Snyder et al. 2010). In this same study, the expression of transferrin in BALF was significantly lower in RAO-affected horses compared to airway disease-affected horses (IAD) and control horses. Because transferrin is a negative acute-phase protein, a decrease in response to inflammation is expected with both RAO and IAD. The relationship between transferrin and pulmonary inflammation is not as clear as that of secretoglobin. Transferrin concentrations may change with the duration and severity of inflammation, and thus the discrepancy in results between studies is not surprising. These differences suggest that secretoglobin and transferrin may be useful as biomarkers or as possible treatment targets for RAO (Miskovic Feutz et al. 2015).

Other studies, however, have used ELISA to measure concentrations of some acute-phase proteins in isolation or only in serum. In these cases, local production cannot be assessed. In horses with heaves, haptoglobin was a marker of both acute and chronic systemic inflammation, whereas high concentrations of SAA indicated acute inflammation. There was no difference in serum concentrations of C-reactive protein between healthy horses and horses with heaves (LavoieLamoureux et al. 2012). In this study, the control horses also showed an increase in haptoglobin serum concentrations after hay exposure. This suggests that the magnitude, but not the uniqueness of the systemic inflammatory response distinguishes heaves-affected from healthy horses. The primary role to haptoglobin is to scavenge hemoglobin released into the circulation because of hemolysis or normal red blood cell turnover (Quaye 2008). Serum amyloid A concentrations were determined in horses with equine influenza virus (EIV), equine herpesvirus-4 (EHV-4), Streptococcus equi subspecies equi (S. equi ss equi), inflammatory airway disease (IAD), 
and healthy controls in serum using a stall-side lateral flow immunoassay test. The results showed that the serum amyloid A levels were significantly greater for infectious respiratory diseases (EIV, EHV-4, S. equi ss equi) and horses with IAD compared to control horses. There was a significant difference between viral and bacterial infections and IAD (Viner et al., 2017). A peak in SAA and fibrinogen levels was observed in horses 24 hours after inoculation with $S$. zooepidemicus. In this study, the SAA value also reached peak value earlier than the fibrinogen value (Hobo et al. 2007).

\section{CONCLUSIONS}

This seems to be the first study in which ceruloplasmin, transferrin, albumin, $\alpha 1$-antitripsin, immunoglobulin $\mathrm{G}$ heavy, immunoglobulin G light, immunoglobulin A, haptoglobin and acidic glycoprotein concentrations were evaluated in BALF of healthy horses by sodium dodecyl sulfate polyacrylamide gel electrophoresis (SDS-PAGE).

Since only healthy horses were studied, the reference values for acute-phase proteins obtained can be a basis for studies of pulmonary pathologies. In healthy horses, the values are very low, but changes in clinical condition can cause a rapid response and the rate of synthesis is the only factor that affects blood concentration.

Acknowledgements.- The authors thank Dr. J.J. Fagliari for the assistance in developing and conducting the assays. This study was financed in part by the "Coordenação de Aperfeiçoamento de Pessoal de Nível Superior" (CAPES) - Finance Code 001, and the "Conselho Nacional de Desenvolvimento Científico e Tecnológico” (CNPq).

Conflict of interest statement.- The authors have no conflicts of interest to declare.

\section{REFERENCES}

Barton A.K., Wirth C., Bondzio A., Einspanier R. \& Gehlen H. 2017. Are pulmonary hemostasis and fibrinolysis out of balance in equine chronic pneumopathies? J. Vet. Sci. 18(3):349-357. <https://doi.org/10.4142/ jvs.2017.18.3.349><PMid:28057902>

Borges A.S., Divers T.J., Stokol T. \& Mohammed O.H. 2007. Serum iron and plasma fibrinogen concentrations as indicators of systemic inflammatory diseases in horses. J. Vet. Intern. Med. 21(3):489-494. <http://dx.doi. org/10.1892/0891-6640(2007)21[489:siapfc]2.0.co;2><PMid:17552456>

Bullone M., Lagarde M., Vargas A. \& Lavoie J.P. 2015. Serum surfactant protein $\mathrm{D}$ and haptoglobin as potential biomarkers for inflammatory airway disease in horses. J. Vet. Intern. Med. 29(6):1707-1711. <http://dx.doi. org/10.1111/jvim.13602><PMid:26289543>

Couëtil L.L., Cardwell J.M., Gerber V., Lavoie J.P., Léguillette R. \& Richard E.A. 2016. Inflammatory airway disease of horses - revised consensus statement. J. Vet. Intern. Med. 30(2):503-515. <http://dx.doi.org/10.1111/ jvim.13824><PMid:26806374>

Couëtil L.L., Hoffman A.M., Hodgson J., Buechner-Maxwell V., Viel L., Wood J.L. \& Lavoie J-.P. 2007. Inflammatory airway disease of horses. J. Vet. Intern. Med. 21(2):356-361. <http://dx.doi.org/10.1892/0891-6640(2007)21[356:ia doh]2.0.co; $2><$ PMid:17427403>

Crisman M.V., Scarratt W.K., \& Zimmerman K.L. 2008. Blood proteins and inflammation in the horse. Vet. Clin. N. Am., Equine Pract. 24(2):285-297. <http://dx.doi.org/10.1016/j.cveq.2008.03.004><PMid:18652956>

Hobo S., Niwa H. \& Anzai T. 2007. Evaluation of serum amyloid A and surfactant protein I sera for identification of the clinical condition of horses with bacterial pneumonia. J. Vet. Med. Sci. 69(8):827-830.<http://dx.doi. org/10.1292/jvms.69.827><PMid:17827889>
Hultén C. \& Demmers S. 2002 Serum amyloid A (SAA) as an aid in the management of infectious disease in the foal: comparison with total leucocyte count, neutrophil count and fibrinogen. Equine Vet. J. 34(7):693-698. <http://dx.doi.org/10.2746/042516402776250360 ><PMid:12455840>

Jacobsen S. 2007. Review of equine acute-phase proteins. Proceedings of 53th Annual Convention of the American Association of Equine Practitioners, Orlando, FL, p.230-235.

Kyd J.M., Foxwell A.R. \& Cripps A.W. 2001. Mucosal immunity in the lung and upper airway. Vaccine 19(17/19):2527-2533.<http://dx.doi.org/10.1016/ s0264-410x(00)00484-9> <PMid:11257388>

Lavoie-Lamoureux A., Leclere M., Lemos K., Wagner B. \& Lavoie J.P. 2012. Markers of systemic inflammation in horses with heaves. J. Vet. Intern. Med. 26(6):1419-1426. <http://dx.doi.org/10.1111/j.1939-1676.2012.00993.x> <PMid:22925172>

Miskovic Feutz M., Couetil L.L., Riley C.P., Zhang X., Adamec J. \& Raskin R.E. 2015. Secretoglobin and transferrin expression in bronchoalveolar lavage fluid of horses with chronic respiratory disease. J. Vet. Intern. Med. 29(6):16921699. <http://dx.doi.org/10.1111/jvim.13604> <PMid:26332291>

Moore B.R., Krakowka S., Mcvey D.S., Cumminss J.M. \& Robertson J.T. 1997. Inflammatory markers in bronchoalveolar lavage fluid of Standardbred racehorses with inflammatory airway disease: response to interferon-alpha. Equine Vet. J. 29(2):142-147.<http://dx.doi.org/10.1111/j.2042-3306.1997. tb01656.x><PMid:9104564>

Out T.A., Jansen H.M., van Steenwijk R.P., Nooijer M.J., van de Graaf E.A. \& Zuijderhoudt F.M.J. 1987. ELISA of ceruloplasmin and alpha-2-macroglobulin in paired bronchoalveolar lavage fluid and serum samples. Clin. Chim. Acta 165(2/3):277-288. <http://dx.doi.org/10.1016/0009-8981(87)90172-0> $<$ PMid:2443279>

Persson C.G.A. 1991. Plasma exudation in the airways: mechanisms and function. Eur. Respir. J. 4(10):1268-1274. <PMid:1804675>

Quaye I.K. 2008. Haptoglobin, inflammation and disease. Trans. R. Soc. Trop. Med. Hyg. 102(8):735-742. <http://dx.doi.org/10.1016/j.trstmh.2008.04.010> <PMid:18486167>

Snyder J.C., Reynolds S.D., Hollingsworth J.W., Zhuowei Li., Kaminski N. \& Stripp B.R. 2010. Clara cells attenuate the inflammatory response through regulation of macrophage behavior. Am. J. Respir. Cell Mol. Biol. 42(2):161171. <http://dx.doi.org/10.1165/rcmb.2008-03530C><PMid:19423773>

Sweeney C.R., Humber K.A. \& Roby K.A.W. 1992. Cytologic findings of tracheobronchial aspirates from 66 Thoroughbred racehorses. Am. J. Vet Res. 53(7):1172-1175. <PMid:1497188>

Upragarin N., Landman WJ., Gaastra W. \& Gruys E. 2005. Extrahepatic production of acute-phase serum amyloid A. Histol. Histopathol. 20(4):1295-1307. <http://dx.doi.org/10.14670/HH-20.1295><PMid:16136510>

Viner M., Mazan M., Bedenice D., Mapes S. \& Pusterla N. 2017. Comparison of serum amyloid $A$ in horses with infectious and noninfectious respiratory diseases. J. Equine Vet. Sci. 49:11-13. <http://dx.doi.org/10.1016/j. jevs.2016.09.005>

Viscardi V., Lopes A.C.G., Beling J.C.F., Gioia G.V., Torres Filhos R.A., Lessa D.A.B. \& Alencar N.X. 2015. Effects of single and duplicate infusions of $250 \mathrm{~mL}$ of saline solution in the cytological evaluation of bronchoalveolar lavage in equines. Braz. J. Vet. Med. 37(1):33-35.

Wilkins P.A. 2003. Lower airway diseases of the adult horse. Vet. Clin. N. Am., Equine Pract. 19(1):101-121. <http://dx.doi.org/10.1016/s07490739(02)00069-x><PMid:12747664>

Wysocka B. \& Kluciński W. 2015. Cytological evaluation of tracheal aspirate and broncho-alveolar lavage fluid in comparison to endoscopic assessment of lower airways in horses with recurrent airways obstruction or inflammatory airway disease. Pol. J. Vet. Sci. 18(3):587-597.<http://dx.doi.org/10.1515/ pjvs-2015-0076> <PMid:26618592>

Yang F., Friedrichs W.E., Navarijo-Ashbaugh A.L., de Graffenried L.A., Bowman B.H. \& Coalson J.J. 1995. Cell type-specific and inflammatory-induced expression of haptoglobin gene in lung. Lab. Invest. 73(3):433-440. <PMid:7564277> 